\title{
Eksistensi Yesus Kristus dalam Perjanjian Baru
}

Federans Randa II

Kepala Unit PPKM, Sekolah Tinggi Teologi Erikson-Tritt, Manokwari

hance.randa@gmail.com

\begin{abstract}
When God created the first humans, namely Adam and Eve, they were both created in the image of God without any sin in humans. But humans eventually fell into sin because of the wrong choices of humans by violating God's commandments by eating the fruit of the knowledge of good and evil which was forbidden by God to be eaten, because when humans eat them, they must die and death is what makes humans sin and lose holiness. God of himself (Rom. 3:23). Sin makes humans separate from God and humans cannot reach God because of the enmity that occurs between humans and God. Sin led man to destruction and eternal punishment of God. However, it was because of God's great love for humans who were specially created in the image of God, so that God took the initiative to deliver and save mankind from destruction and God's eternal punishment which would be bestowed upon mankind because of man's own sin.
\end{abstract}

Keywords: human being; Jesus Christ; way of salvation

\begin{abstract}
Abstrak: Ketika Allah menciptakan manusia pertama yakni Adam dan Hawa, maka keduanya diciptakan segambar dengan Allah tanpa ada dosa dalam diri manusia. Namun manusia akhirnya jatuh dalam dosa oleh karena pilihan manusia yang salah dengan melanggar perintah Allah dengan memakan buah pengetahuan yang baik dan yang jahat yang dilarang oleh Allah untuk dimakan, sebab ketika manusia memakannya pastilah mati dan kematian itulah yang membuat sehingga manusia menjadi berdosa dan kehilangan kekudusan Allah dari dirinya (Rm. 3:23). Dosa membuat manusia terpisah dengan Allah dan manusia tidak bisa mencapai Allah karena perseteruan yang terjadi antara manusia dengan Allah. Dosa membawa manusia kepada kebinasaan dan hukuman kekal Allah. Namun karena kasih Allah yang sangat besar terhadap manusia yang diciptakan istimewa yakni segambar dengan Allah, sehingga Allah mengambil inisiatif untuk melepaskan dan menyelamatkan manusia dari kebinasaan dan hukuman kekal Allah yang akan ditimpahkan kepada manusia oleh karena dosa manusia itu sendiri.
\end{abstract}

Kata kunci: jalan keselamatan; manusia; Yesus Kristus

\section{PENDAHULUAN}

Yesus Kristus merupakan pusat pemberitaan baik dalam Perjanjian Lama maupun dalam Perjanjian Baru. Keberadaan Yesus Kristus dalam Perjanjian Lama dan Perjanjian Baru memang berbeda, sebab dalam Perjanjian Lama keberadaan Yesus Kristus tidak dalam bentuk permanen karena pada Perjanjian Lama Yesus Kristus belum nampak dalam wujud manusia secara jasmani. Sedangkan Yesus Kristus dalam Perjanjian Baru keberadaan-Nya dalam bentuk jasmani karena Yesus Kristus telah berinkarnasi secara daging dan permanen. Arti dari permanen adalah di mana Yesus Kristus bisa dilihat dan tinggal menetap di bumi bersama dengan manusia lainnya. 
Ketika manusia jatuh dalam dosa, maka manusia benar-benar sangat membutuhkan Yesus Kristus dalam kehidupan manusia, sebab hanya Yesus Kristus saja yang bisa menolong manusia untuk tidak masuk dalam penghukuman kekal Allah. Ketiga Pribadi Allah yakni Bapa, Anak dan Roh Kudus memiliki peranan-Nya masing-masing, dan Yesus Kristus memiliki peranan penting dalam kehidupan manusia yakni menyelamatkan manusia dari dosa dan membebaskan manusia dari kebinasaan kekal Allah..

\section{Yesus Kristus dalam Perjanjian Baru}

Berbicara mengenai Yesus Kristus dalam Perjanjian Baru tidaklah asing bagi manusia, karena tidak ada seorang pun yang tidak pernah melihat Yesus Kristus yang adalah Allah sendiri. Allah telah menjelma menjadi wujud yang kelihatan dengan tujuan agar semua manusia tanpa terkecuali dapat melihat Allah dengan jelas melalui Pribadi Kedua dari Allah Tritunggal yakni Yesus Kristus. Seluruh isi Alkitab dalam Perjanjian Baru secara khusus selalu menyoroti Yesus Kristus sebagai sentral utama yang penting bagi keselamatan manusia.

Dalam Perjanjian Baru di mana lebih mudah manusia mengenal Anak Allah di dalam Pribadi Yesus Kristus dibandingkan dalam Perjanjian Lama. Mengapa demikian karena dalam Perjanjian Lama Pribadi Yesus Kristus belum datang dalam wujud yang kelihatan secara permanen sehingga dengan mudah manusia dapat mengenalnya, tetapi ketika dalam Perjanjian Baru Yesus Kristus datang dalam wujud yang kelihatan sehingga dengan mudah manusia dapat melihat dan mengenal Anak Allah.

Tujuan Allah mengutus Anak-Nya Yesus Kristus datang ke dalam dunia, karena Allah melihat bahwa manusia ketika jatuh dalam dosa sedang menuju kepada kebinasaan dan hukuman kekal Allah. Ketika manusia jatuh dalam dosa Allah langsung datang dan mencari manusia sendiri tanpa melalui perantara yang lain. Mengapa Allah tidak mengutus malaikat untuk mencari tahu kejatuhan manusia dalam dosa, tetapi Allah yang langsung datang berjumpa dan bertemu dengan Adam dan Hawa dengan tujuan untuk mendengar langsung alasan apa yang Adam dan Hawa berikan kepada Allah yang membuat Adam dan Hawa bisa jatuh ke dalam dosa.

Sejak zaman Perjanjian Lama Allah melihat bahwa manusia sudah berusaha dengan berbagai cara dan metode untuk mencari dan mencapai Allah, namun semuanya tidak ada satupun yang berhasil karena dosa membuat manusia tidak bisa mencapai Allah. Manusia membutuhkan kehadiran Allah melalui Pribadi Yesus Kristus untuk menolong dan menyelamatkan manusia, sehingga manusia dapat terhindar dari hukuman kekal yang diberikan Allah kepada manusia berdosa yang tidak mau bertobat dan percaya kepada Yesus Kristus.

Semua yang Allah lakukan kepada manusia, karena Allah sangat mengasihi manusia sebagai ciptaan yang istimewa yakni diciptakan segambar dan serupa dengan Allah. Sekalipun gambar dan rupa Allah telah rusak akibat dosa dalam diri manusia, namun tidak berarti mengurangi kasih Allah kepada manusia. Kasih Allah 
tidak terpengaruh dengan berubahnya manusia dari manusia yang diciptakan kudus dan suci telah berubah menjadi manusia yang penuh dengan dosa. Manusia diciptakan menurut gambar dan rupa Allah tidak berarti bahwa manusia adalah Allah. Stephen Tong mengatakan: "Manusia diciptakan menurut peta dan teladan Allah, berarti manusia seperti Allah, tetapi manusia bukan Allah."1

Kasih Allah sangat nyata bagi manusia terbukti dengan memberikan atau mengaruniakan Anak-Nya Yesus Kristus datang untuk memperbaharui dan memberikan identitas baru bagi setiap orang yang mau menerima dan percaya kepada Yesus Kristus. Pemberian dan penganugerahkan identitas baru oleh Allah kepada manusia tidak bersifat memaksa, namun semua kembali kepada manusia melalui kehendak bebas manusia untuk dapat memilih dan menentukan akan masa depannya, karena ada dua tempat yang disediakan Allah bagi manusia setelah manusia jatuh dalam dosa yakni yang tidak mau bertobat akan mendapatkan hukuman kekal Allah dan yang mau bertobat dan percaya kepada Yesus Kristus akan mendapatkan hidup yang kekal.

\section{Inkarnasi Yesus Kristus}

Kata Inkarnasi sebenarnya tidak terdapat dalam Alkitab, tetapi kata ini diambil dari

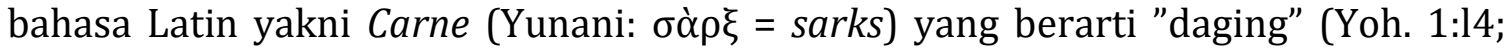
Rm. 8:3; Ef. 2:15;1 Tim. 3:16; 1 Ptr. 4:1; 1 Yoh. 4:2; 2 Yoh. 7). Istilah inkarnasi merupakan hal yang sangat penting untuk menunjukkan akan Allah yang benarbenar mau menjadi sama dengan manusia dan dapat tinggal bersama dengan manusia. Kata menjadi manusia bukan berarti bahwa segala eksistensi-Nya sama dengan manusia yang adalah pribadi yang berdosa dan diciptakan. Hal ini juga dijelaskan oleh Evans mengenai istilah dari inkarnasi itu sendiri yang mengatakan: "Allah menyertai kita." Istilah teologis untuk itu ialah "inkarnasi" atau Allah yang "menjadi daging." Istilah inkarnasi berasal dari kata Latin yakni Carne yang mengandung arti "daging."

Penggunaan istilah inkarnasi mengandung arti yang sama dengan telah menjadi manusia atau menjelma menjadi manusia. Dalam Yohanes 1:14 dalam

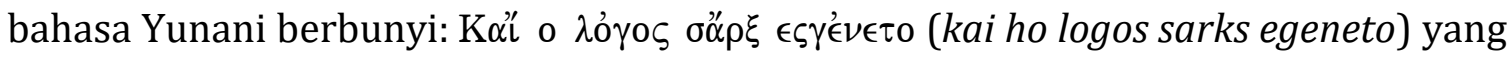
berarti "dan Firman itu telah menjadi daging," yang kemudian diterjemahkan ke

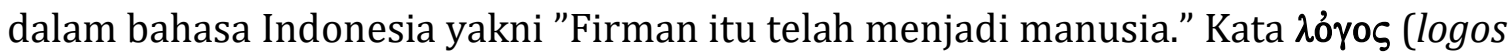
= firman) yang telah menjadi manusia dapat dilihat dalam Yohanes 1:1 yang menjelaskan mengenai logos dalam tiga pengertian yakni Perkataan, Pribadi Yesus Kristus dan Allah sendiri. Dari pengertian ketiga logos tersebut barulah dapat terlihat jelas dalam Yohanes 1:14 di mana logos yang dimaksud tidak menunjuk kepada perkataan maupun kepada Allah, tetapi menunjuk kepada Pribadi Yesus Kristus.

${ }^{1}$ Stephen Tong. Peta dan Teladan Allah (Surabaya: Penerbit Momentum, 2013), 25.

${ }^{2}$ Anthony T. Evans, Teologi Allah, Allah Kita Maha Agung (Malang: Yayasan Penerbit Gandum Mas, 1999), 344. 
Kata "telah menjadi daging (manusia)" menunjukkan bahwa Yesus Kristus yang adalah Allah benar-benar telah menjadi manusia dan ini merupakan peristiwa yang sudah terjadi di masa lampau. Manusia pada zaman Yesus Kristus telah melihat Allah yang selama ini disampaikan atau dinubuatkan dalam Perjanjian Lama. Ketika Yesus Kristus telah menjadi manusia, maka setiap saat manusia yang berdosa dapat memandang dan melihat Allah melalui Pribadi Yesus Kristus, karena Yesus Kristus adalah Allah sendiri.

Sebelum Tuhan Yesus Kristus menjelma menjadi manusia, Roh Kudus menempatkan benih Ilahi dalam rahim Maria dan dikandung selama sembilan bulan dan kemudian dilahirkan sebagai manusia. Selama benih Ilahi berada dalam rahim Maria, maka proses pertumbuhan dari benih Ilahi tidak menjadi tanggung jawab Maria, tetapi semuanya itu merupakan pekerjaan dan tanggung jawab Roh Kudus. Maria hanya dipinjamkan rahimnya untuk meletakkan benih Ilahi karena Maria adalah wanita yang mendapatkan kasih karunia dari Allah untuk menempatkan benih Ilahi dalam rahimnya sehingga nantinya akan dilahirkan sebagai seorang manusia, dan dalam proses kelahiranpun semuanya itu adalah tanggung jawab Roh Kudus, sehingga tidak ada bagian yang dari tubuh Maria dapat mengalir ke dalam benih Ilahi, sehingga ketika benih Ilahi itu dilahirkan tetap dalam keadaan kudus dan suci.

Sekalipun benih Ilahi ditempatkan dalam rahim Maria yang berdosa, tetapi tidak berarti bahwa benih Ilahi telah tercemar atau terkontaminasi dengan dosa Maria. Roh Kudus memprotek (melindungi) dan menjaga sehingga tidak ada darah sedikitpun yang mengalir ke dalam benih Ilahi. Hal ini secara logika dan akal manusia mustahil dan tidak mungkin karena bagaimanapun juga benih Ilahi membutuhkan asupan dari Maria yang sedang mengandung-Nya, tetapi manusia yang sangat terbatas dan penuh dengan dosa tidak mampu melebihi pikiran Allah, karena bagi Allah tidak ada perkara yang sulit dan sukar untuk dapat Allah kerjakan.

Allah dapat melakukan yang tidak ada menjadi ada, sehingga pekerjaan seperti memberi makanan kepada benih Ilahi yang ada dalam rahim Maria bagi Allah merupakan pekerjaan yang gampang dan mudah. Bagi Allah segala sesuatu mungkin dan tidak ada yang mustahil bagi Allah untuk melakukan segala pekerjaan yang manusia sendiri tidak mampu untuk melakukannya, sebab manusia sangat terbatas dan Allah tidak terbatas.

\section{Kehidupan dan Pelayanan Yesus Kristus}

Setelah Yesus Kristus telah menjadi manusia dan dilahirkan dari perawan Maria, maka Yesus Kristus telah masuk dalam dunia nyata yang mana manusia dapat melihat Allah di dalam Pribadi Yesus Kristus. Proses pertumbuhan Yesus Kristus sebagai manusia tidak berbeda dengan manusia yang lain, cuma yang berbeda antara Yesus dengan manusia adalah bahwa Yesus Kristus sebagai manusia tanpa dosa, sementara manusia hidup dalam dosa. Yesus Kristus dibawah asuhan orang tuanya yakni Yusuf dan Maria. Jadi secara keturunan Yesus Kristus memiliki 
keturunan yang sah sebagai ahli waris dari Yusuf dan Maria yang berasal dari Nazaret karena itu Yesus disebut sebagai orang Nazaret.

Ketika Yesus Kristus semakin besar dan dewasa dimana terlihat hikmat Yesus Kristus semakin dikagumi banyak orang karena perkataan yang diucapkan Yesus Kristus penuh dengan kuasa dan menjadi berkat bagi banyak orang. Kehidupan Yesus Kristus selalu menjadi pusat perhatian banyak orang apalagi ketika Yesus Kristus di baptis dan masuk dalam pelayanan Yesus Kristus semakin dicintai banyak orang. Firman Tuhan berbunyi:

Ketika seluruh orang banyak itu telah dibaptis dan ketika Yesus juga dibaptis dan sedang berdoa, terbukalah langit, dan turunlah Roh Kudus dalam rupa burung merpati ke atas-Nya. Dan terdengarlah suara dari langit: "Engkaulah Anak-Ku yang Kukasihi, kepada-Mulah Aku berkenan." Ketika Yesus memulai pekerjaan-Nya, Ia berumur kira-kira tiga puluh tahun dan menurut anggapan orang, Ia adalah anak Yusuf, anak Eli. (Luk. 3:21-23).

Yesus Kristus setelah di baptis oleh Yohanes Pembaptis barulah Yesus Kristus mulai masuk dalam kehidupan pelayanan-Nya. Setiap hari Yesus Kristus berkeliling kota dan desa untuk memberitakan kabar keselamatan dengan tujuan agar jangan sampai ada manusia yang menuju kepada kebinasaan dan hukuman kekal Allah. Yesus Kristus mulai dikenal banyak orang ketika Yesus Kristus mulai masuk dalam dunia pelayanan, karena hampir setiap hari Yesus Kristus berkeliling tempat untuk memberitakan Injil keselamatan kepada setiap orang, karena kematian adalah suatu peristiwa yang tidak diketahui manusia, sehingga jangan sampai manusia mati dan belum sempat mendengar kabar keselamatan hingga akhirnya manusia mati binasa. Nazaret adalah kota kecil yang merupakan tempat Yesus Kristus dibesarkan oleh kedua orang tuanya yakni Yusuf dan Maria. J. W. Charley mengatakan: "Kota di Galilea, tempat tinggal Yusuf dan Maria, juga Yesus selama kira-kira 30 tahun sampai Dia ditolak (Luk. 2:39; 4:16, 28-31). Karena itulah Dia disebut Yesus dari Nazaret."3

Pelayanan Yesus Kristus yang begitu singkat ketika dihitung mulai sejak Yesus Kristus dibaptis oleh Yohanes Pembaptis dalam usia 30 tahun. Karena kehidupan pelayanan Yesus Kristus di dunia ini hanya kira-kira 3 tahun saja, setelah itu Yesus Kristus ditangkap dan disalibkan lalu mati dan dikuburkan pada usia 33 tahun. Bagi Yesus Kristus waktu yang singkat bukan ukuran untuk tidak memberitakan kabar keselamatan bagi umat manusia. Waktu yang hanya 3 tahun bagi Yesus Kristus sudah cukup dan sempurna karena semua pekerjaan yang diberikan Bapa kepada Yesus Kristus telah dikerjakan dengan baik dan sempurna dan tidak ada satu pekerjaan Bapa yang belum diselesaikan oleh Yesus Kristus sebelum Yesus Kristus disalibkan di atas kayu salib.

Kehidupan pelayanan Yesus Kristus yang terbilang begitu singkat, namun Pemberitaan Injil keselamatan sudah menyebar ke berbagai kota dan desa, sehingga banyak orang sudah mendengar dan menerima Injil keselamatan yang dari Allah

3J. W. Charley, Ensiklopedi Alkitab Masa Kini, pen., M. H. Simanungkalit., peny., H. A. Oppusunggu (Jakarta: Yayasan Komunikasi Bina Kasih, 1997), 142. 
melalui Pribadi Yesus Kristus. Salah satu keberhasilan dalam pelayanan Yesus Kristus adalah ketika Yesus Kristus memilih 12 orang sebagai murid-murid-Nya (Mat. 10:1-4; Mrk. 3:13-19; Luk. 6:12-16). Tujuan dari Yesus Kristus memilih 12 orang menjadi murid-murid-Nya untuk melanjutkan misi Amanat Agung Allah yakni pergi dan memberitakan Injil keselamatan (Mat. 28:18-20), karena Yesus Kristus tahu bahwa keberadaan dan kehadiran di dunia ini secara manusia hanya singkat saja.

Yesus Kristus yang adalah Allah ketika menjelma menjadi manusia, maka Yesus Kristus adalah satu-satunya manusia di dunia ini yang tidak berdosa dan memiliki dua sifat yang berbeda dalam satu tubuh yang sama yakni sifat Allah dan sifat manusia. Sepanjang pelayanan Yesus Kristus di dunia ini Yesus Kristus selalu memperlihatkan dua sifat yang berbeda untuk menunjukkan bahwa Yesus Kristus adalah Allah yang sempurna dan Yesus Kristus adalah manusia yang sempurna.

Ketika Yesus tampil sebagai Allah dimana Yesus dapat menunjukkan sesuatu dengan melakukan berbagai tanda dan mujizat, karena tidak ada seorangpun di dunia yang dapat melakukan mujizat selain Allah sendiri. Salah satu bukti bahwa Yesus Kristus adalah Allah ketika Filipus bertanya kepada Yesus Kristus tunjukkanlah Bapa bagi mereka, tetapi Yesus berkata bahwa Yesus Kristus dan Bapa adalah sama, barangsiapa telah melihat Yesus sebagai Pribadi Anak Allah yang diutus ke dunia ini sama saja bahwa mereka juga telah melihat Bapa, karena Bapa dan Yesus Kristus adalah satu (Yoh. 14:6-13). Selain itu juga mengenai doa Yesus kepada murid-murid-Nya di mana Yesus Kristus juga menyatakan bahwa Diri-Nya dengan Bapa adalah satu sekalipun Bapa dan Yesus berbeda secara Pribadi (Yoh. 17:20-26).

Bapa dan Yesus Kristus satu dalam kesetaraan sebagai Allah, artinya bahwa Bapa tidak lebih tinggi dari pada Anak (Yesus Kristus), sebaliknya juga bahwa Anak (Yesus Kristus) tidak lebih rendah dengan Bapa, karena keduanya satu dalam hakekat sebagai Allah dan setara artinya antara Bapa dan Yesus Kristus adalah sama-sama adalah Allah. Oleh karena itu ketika Yesus Kristus dalam kehidupan pelayanan-Nya di tengah-tengah dunia ini Yesus selalu melakukan berbagai tanda dan mujizat untuk menunjukkan dan membuktikan bahwa Yesus Kristus adalah Allah.

Sementara Yesus Kristus sebagai manusia menunjukkan bahwa Yesus Kristus benar-benar manusia mulai dari proses ketika Yesus Kristus dalam rahim seorang perawan Maria yang dikandung selama 9 bulan, dan kemudian dilahirkan sebagai manusia (Luk. 2:1-7). Yesus Kristus mengalami pertumbuhan sebagai manusia dari masa kanak-kanak sampai dewasa (Luk. 2:8-52). Yesus Kristus sebagai manusia maka Yesus Kristus bisa ikut merasakan apa yang dialami oleh manusia yang lain. Bahkan Yesus Kristus semakin disukai dan dicintai oleh Allah dan banyak orang karena hikmat yang dimiliki oleh Yesus Kristus begitu luar biasa. Banyak orang kagum kepada Yesus Kristus karena sepanjang sejarah manusia, dimana belum pernah dijumpai seseorang yang mempunyai dan memiliki hikmat yang luar biasa. 
Sebagai manusia Yesus Kristus melakukan ketradisian Yahudi seperti di sunat pada hari kedelapan (Luk. 2:21), kemudian Yesus Kristus menjalani hari-hari hidupnya seperti manusia sekalipun saat itu Yesus Kristus belum dikenal banyak orang. Yesus Kristus mulai dikenal banyak orang ketika Yesus Kristus dibaptis dan terjun dalam dunia pelayanan. Sejak itulah Yesus Kristus secara manusia mulai dikenal banyak orang dan kemana Yesus Kristus pergi banyak orang berbondongbondong mengikuti-Nya dengan tujuan untuk mendengarkan apa yang disampaikan bahkan melihat tanda-tanda dan mujizat yang dilakukan oleh Yesus Kristus.

Sebagai manusia Yesus Kristus pernah makan (Mat. 9:10), karena jika manusia tidak makan akan menjadi lemah dan semua orang juga memerlukan hal yang sama, Yesus pernah sedih (Mrk. 14:34), sebagai manusia Yesus merasa sedih karena takut menghadapi murka Allah yang akan ditimpahkan kepada-Nya. Yesus Kristus harus menanggung seluruh dosa umat manusia. Yesus juga pernah marah (Mrk. 3:1-5). Orang banyak selalu ingin mencari kesalahan yang ada pada Yesus, tetapi Yesus tahu kemunafikan hati mereka, sehingga Yesus marah kepada mereka. Kemarahan Yesus Kristus tidak menimbulkan dosa dalam diri-Nya. Yesus juga pernah merasa lapar (Mrk. 11:12). Secara manusia Yesus merasa lapar karena belum makan, sehingga menimbulkan rasa lapar dalam dalam diri Yesus. Hal ini juga ditegaskan oleh Paulus Daun mengatakan:

Yesus sebagai manusia, mengalami penderitaan yang sama seperti manusia. Ia mengalami apa yang dinamakan kelaparan, kehausan, kelelahan, kehinaan, kemiskinan, penderitaan, penganiayaan, pencobaan, air mata dan sebagainya. Sebab itu, penulis Ibrani mengatakan, "Sebab Imam Besar yang kita punya, bukanlah imam besar yang tidak dapat turut merasakan kelemahan-kelemahan kita, sebaliknya sama dengan kita, Ia telah dicobai, hanya tidak berbuat dosa" (Ibr. 4:15).4

Dari beberapa hal yang disebutkan di atas semuanya menunjuk kepada kemanusiaan Yesus. Sebab apa yang Yesus alami juga dialami oleh setiap orang yang menunjukkan bahwa mereka juga adalah manusia. Kemanusiaan Yesus Kristus dapat terlihat sampai kepada kematian-Nya di atas kayu salib sebagai orang yang dijadikan berdosa oleh karena pelanggaran dan kesalahan manusia yang ditimpahkan kepada Yesus Kristus di atas kayu salib.

\section{Karya Keselamatan Yesus Kristus}

Karya terbesar Allah bagi manusia melalui Pribadi Yesus yang datang untuk menjadikan manusia berharga di mata Allah dengan cara menyelamatkan manusia dari dosa dan dari hukuman kekal Allah. Sebenarnya karya keselamatan Allah di dalam Yesus sudah dinubuatkan dalam Perjanjian Lama, namun Pribadi yang akan menyelamatkan manusia dari dosa belum diketahui secara jelas oleh manusia di Perjanjian Lama, sehingga dapat dipastikan bahwa karya keselamatan Yesus bukan hanya terjadi pada zaman Perjanjian Baru tetapi telah dibuktikan bahwa sejak Perjanjian Lama karya Yesus sudah dinyatakan oleh Allah melalui para nabi untuk dinubuatkan, sehingga semuanya baru terlihat jelas ketika dalam Perjanjian Baru.

${ }^{4}$ Paulus Daun, Kristologia (Doktrin Tentang Allah), Pneumatologia (Doktrin Tentang Roh Kudus) (Manado: Yayasan Daun Family, 2006), 92-93. 
Karya keselamatan di dalam Yesus Kristus melalui satu prosesi yang sistematis yang telah Allah rancang begitu indah dan sempurna sehingga tahapan demi tahapan dilalui oleh Yesus dengan baik dan sesuai dengan rencana kerja Allah. Karya keselamatan Allah ada dalam satu rencana Allah, sehingga karya keselamatan tidak ada yang diluar rencana Allah bahkan tidak ada satupun yang tidak diketahui oleh Allah. Karya keselamatan dimaksudkan untuk mengembalikan identitas diri manusia yang telah dihancurkan oleh dosa dalam diri manusia, sehingga manusia menjadi seteru Allah dan manusia kehilangan kekudusan Allah.

Melalui karya keselamatan di dalam Yesus dimana manusia dapat memiliki dan mendapatkan kembali apa yang pernah manusia dapatkan dari Allah yakni sebagai orang kudus dan memiliki persekutuan yang indah dengan Allah. Manusia tidak bisa mendapatkan kembali apa yang telah hilang dari manusia dengan cara usaha dan kerja keras manusia, sebab untuk mendamaikan manusia yang berdosa dengan Allah yang Mahakudus, maka harus ada orang yang bisa menjembatani dan semuanya itu hanya didapatkan di dalam Yesus. Karya keselamatan Yesus merupakan kasih karunia Allah yang diberikan kepada manusia secara gratis (Ef. 2:8-9). Karya keselamatan bukanlah program kerja manusia tetapi karya keselamatan adalah program kerja Allah yang telah diproklamasikan ketika manusia jatuh ke dalam dosa (Kej. 3:15). Allah tidak sembarangan untuk membuat dan merencanakan suatu program, tetapi semua program Allah diatur secara baik dan benar, sehingga semuanya dapat berjalan sesuai dengan apa yang telah Allah rencanakan sejak masa kekekalan Allah. Chris Marantika mengatakan:

Allah adalah Pribadi yang bekerja dengan teratur dan rapih. Allah mempunyai perencanaan (master plan) bagi dunia dengan sasaran dan sarana-sarana yang sudah disiapkan dikekekalan masa lampau. Allah memiliki suatu program strategi kerja yang obyektif (Management by Objective). Dan karena dunia ini adalah proyek Allah, maka langkah-langkah menuju pencapaian sasaran itu telah ditetapkan pula olehNya. ${ }^{5}$

Allah adalah perencana program kerja yang rapih dan baik, sehingga semua program kerja Allah terlihat berjalan dengan sangat baik dan semuanya itu berpusat hanya kepada Pribadi Yesus Kristus yang telah ditentukan Allah untuk menyelamatkan manusia dari dosa dan dari hukuman kekal Allah. Dosa membuat manusia tidak bisa keluar dan tidak bisa terlepas dari ikatan dosa yang selama ini mengikat diri manusia. Yesus Kristus datang ke dalam dunia sebenarnya sebagai klimaks atau puncak dari rencana Allah dalam masa kekekalan yang berkenan dengan keselamatan manusia agar melalui Yesus Kristus manusia bisa keluar ikatan dosa. David L. Baker mengatakan: "Alkitab menyaksikan kedatangan Yesus Kristus sebagai puncak sejarah keselamatan itu."6 Memang benar bahwa keselamatan hanya ada di dalam Yesus Kristus, sebab tanpa Yesus Kristus maka tidak ada satu orang di dunia ini yang bisa datang dan memperoleh hidup yang kekal.

${ }^{5}$ Chris Marantika, Masa Depan Dunia Ditinjau Dari Sudut Alkitab. Eskatologi (Yogyakarta: Iman Press, 2004), 45.

${ }^{6}$ David L. Baker, Satu Alkitab Dua Perjanjian (Jakarta: BPK Gunung Mulia, 2000), 291. 


\section{Penderitaan Yesus Kristus}

Dalam mencapai karya keselamatan Allah di dalam Yesus Kristus maka Yesus Kristus harus melalui suatu penderitaan yang akan dialaminya sebagai manusia. Sekalipun secara manusia rasanya berat dan tidak sanggup untuk menerima cawan Allah yang ditimpahkan kepada-Nya, tetapi bagi Allah inilah merupakan pilihan Allah yang tepat dan benar untuk menyelamatkan manusia dari hukuman kekal Allah. Allah tidak menyediakan cara dan jalan yang lain selain Yesus Kristus harus benar-benar mengalami penderitaan untuk mencapai kesempurnaan Allah dalam karya keselamatan bagi manusia.

Penderitaan yang dialami oleh Yesus Kristus sebenarnya tidak pantas dan kurang layak untuk dialami oleh Yesus, tetapi bagi Allah inilah yang paling terbaik, sebab jalan ini satu-satunya yang disediakan Allah bagi Yesus Kristus. Yesus Kristus harus menerima semua murka Allah dengan cara meminum cawan murka Allah yang akan ditimpahkan kepada Anak-Nya (Yesus Kristus). Sebagai manusia Yesus Kristus benar-benar takut dan tidak sanggup untuk menerima cawan murka Allah yang oleh karena semua perbuatan dan pelanggaran manusia berdosa tanpa terkecuali harus ditimpahkan kepada-Nya yang sebenarnya Yesus Kristus tidak pernah melakukan apa yang seharusnya ditimpahkan kepada-Nya.

Dalam taman Getsemani saat-saat dimana cawan murka Allah itu harus diminum-Nya, dan dalam doa-Nya sebagai manusia kepada Bapa-Nya yang telah mengutus dan mempercayakan pekerjaan ini kepada diri-Nya, Yesus berkata kalau boleh cawan murka Allah yang akan ditimpahkan kepada-Nya dihalau dari Diri-Nya, tetapi Yesus Kristus berkata bukan karena keinginan dan kehendak Diri-Nya sendiri, tetapi semuanya diserahkan kepada kehendak Bapa-Nya (Mat. 26:39; Ibr.

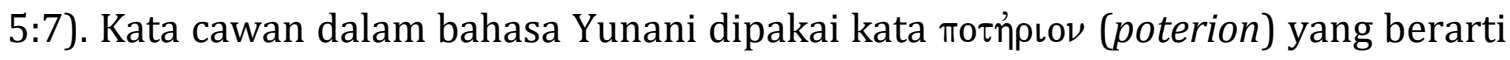
cawan. ${ }^{7}$ Pengertian cawan yang dimaksud dalam ayat ini lebih tepat menunjuk kepada penderitaan Yesus Krisus yang akan dialaminya.

Sekalipun Yesus Kristus memohon kepada Bapa-Nya yang telah mengutus Diri-Nya datang ke dalam dunia yang penuh dengan dosa untuk melakukan semua pekerjaan Bapa-Nya, sehingga ketika menghadapi cawan murka Allah, dimana Yesus Kristus harus memohon kepada Bapa-Nya agar Yesus Kristus tidak egois yang hanya mementingkan Diri-Nya sendiri, tetapi Yesus Kristus menyerahkan sepenuhnya kepada Bapa-Nya yang telah mengutus-Nya. Yesus Kristus tahu bahwa apa yang menjadi pilihan Bapa-Nya itu yang terbaik dan termulia baik Diri-Nya dan juga bagi seluruh umat manusia yang berdosa.

Allah begitu sangat mengasihi Anak-Nya (Yesus Kristus), tetapi lebih-lebih lagi Allah sangat mengasihi manusia sebagai ciptaan yang diciptakan segambar dan serupa dengan Allah yang saat ini hidupnya telah menuju kepada kebinasaan dan hukuman kekal Allah, sehingga Allah lebih memilih mengorbankan satu orang demi menyelamatkan seluruh umat manusia. Jika Yesus Kristus tidak menimum cawan murka Allah, maka dipastikan bahwa tidak ada satu orangpun yang bisa

${ }^{7}$ Barcklay M. Newman JR, Kamus Yunani - Indonesia Untuk Perjanjian Baru, pen., John Miller dan Gerry van Klinken (Jakarta: Penerbit BPK Gunung Mulia, 2012), 138. 
mendapatkan hidup kekal. Karena itu Allah mengijinkan agar Yesus Kristus meminum cawan murka Allah demi menyelamatkan seluruh umat manusia.

Penderitaan yang dialami oleh Yesus Kristus merupakan penderitaan yang tidak bisa dilakukan oleh manusia, karena penderitaan Yesus Kristus untuk memuaskan hati Allah atas dosa-dosa yang selama ini mengikat manusia. Bagi Allah penderitaan Yesus Kristus merupakan pekerjaan klimaks atau pekerjaan puncak yang harus dilakukan oleh Yesus Kristus untuk menyempurnakan seluruh karya penyelamatan Allah yang semuanya terfokus pada penderitaan yang nantinya membawa Diri-Nya di atas kayu salib.

Manusia merupakan obyek atau sasaran Allah dari karya keselamatan di dalam Yesus Kristus, sebab Allah tidak pernah merencanakan agar karya keselamatan di dalam Yesus Kristus disediakan secara umum bagi seluruh ciptaanNya, tetapi hanya dikhususkan dan spesial kepada manusia yang adalah gambar dan rupa Allah yang telah hancur akibat dari dosa dan kesalahan manusia sendiri. J. I. Packer mengatakan: "Sebab objek kasih Allah adalah makhluk rasional yang telah melanggar hukum Allah, yang sifatnya rusak dalam pandangan Allah, yang hanya layak untuk mendapat penghukuman dan dicampakkan dari hadirat-Nya."8

Setiap orang yang berada di luar Kristus menjadikan dirinya sebagai orangorang yang dimurkai oleh Allah, sebab tanpa terkecuali setiap orang yang belum percaya kepada Yesus, maka di hadapan Allah adalah orang-orang yang siap untuk menerima hukuman kekal sebagai akibat dari murka Allah atas dosa yang membawa manusia masuk dalam hukuman kekal Allah. Thomas J. Sappington mengatakan: "Sebelum kita percaya kepada Yesus Kristus, kita dimurkai Allah sama seperti orang-orang lain yang masih di luar Kristus."9

Dampak dari terpisahnya manusia yang berdosa dengan Allah yang Mahakudus akibat dosa yang ada dalam diri manusia yang mengakibatkan Allah murka atas manusia, sehingga mau tidak mau Allah harus menyelamatkan manusia dari dosa, sebab itu maka semua manusia akan menerima murka Allah, tetapi oleh karena kasih Allah yang begitu besar bagi manusia, sehingga murka Allah ditimpahkan kepada Anak-Nya sendiri dengan datang ke dalam dunia dan harus menderita dengan cara meminum cawan murka Allah yang ditimpahkan kepada Yesus Kristus.

Salah satu penderitaan fisik yang dialami oleh Yesus Kristus ketika Yesus Kristus ditangkap dan diadili lalu dicambuk sebagai salah satu bentuk hukuman bagi manusia yang dianggap telah melakukan satu pelanggaran (Mat. 27:26; Mrk. 15:15; Luk. 23:25; Yoh. 19:1). Sekalipun Yesus Kristus ketika diperhadapkan dengan para pembesar seperti Kayafas, Imam Besar (Mat. 26:57-68), Herodes (Luk. 23:812) dan Pilatus (Mrk. 15:1-15). Pilatus sebagai orang yang menentukan mati hidupnya seseorang dan Yesus Kristus tidak ditemukan dan tidak didapatkan satu

8J. I. Packer, Knowing God, pen., Johny The (Yogyakarta: Penerbit ANDI, 2008), 150.

${ }^{9}$ Thomas J. Sappington, Hancurkan Kuasa Iblis Dalam Diri Anda (Yogyakarta: Penerbit Yayasan ANDI, 1998), 46. 
kesalahan atau tidak ada pelanggaran yang diperbuat oleh Yesus Kristus yang membawanya kepada penghukuman, namun oleh karena desakan banyak oranglah yang membuat Pilatus harus menyalibkan Yesus Kristus yang tidak melakukan kesalahan seperti yang dituduhkan banyak orang kepada Yesus karena faktor kebencian.

\section{Penyaliban Yesus Kristus Di Atas Kayu Salib}

Penderitaan Yesus Kristus tidak cukup sampai dengan cara Yesus dicambuk, tetapi orang banyak membawanya sampai kepada penyaliban Yesus Kristus di atas kayu salib. Kayu salib merupakan tempat bagi orang-orang yang telah melakukan satu kejahatan besar dan Yesus Kristus ditempatkan sebagai bilangan orang yang dipandang demikian oleh orang-orang yang sebenarnya tidak mengetahui tentang kesalahan apa yang telah dilakukan oleh Yesus Kristus, namun karena hasutan dari para pembesar dan orang-orang yang punya kepentingan, sehingga Yesus Kristus dijadikan sebagai korban yang harus menerima hukuman salib yang sebenarnya tidak ada satu kesalahan dan kejahatanpun yang telah dibuat oleh Yesus Kristus.

Yesus Kristus disalibkan diantara dua orang yang benar-benar telah melakukan kejahatan, sehingga hukuman yang diberikan kepada dua orang lainnya setimpal dengan perbuatannya, tetapi Yesus Kristus ditempatkan setara dengan dua orang tersebut. Sekalipun Yesus Kristus tidak melakukan kesalahan dan kejahatan, namun salib merupakan jalan yang harus diterima oleh Yesus Kristus untuk mencapai kesempurnaan Allah dalam karya keselamatan yang dikerjakan di dalam Yesus Kristus. Yesus Kristus harus meminum cawan murka Allah melalui penyaliban Yesus Kristus di atas kayu salib.

Setiap orang yang tersalib di atas kayu salib merupakan satu penghinaan yang luar biasa, karena dipandang sebagai seorang penjahat yang telah melakukan satu kesalahan besar yang benar-benar telah memalukan akan dirinya sendiri, juga salib sebagai tempat untuk menghukum mati orang. Karena setiap orang yang telah sampai di atas kayu salib tidak mungkin tidak akan mengalami kematian fisik. Setiap orang yang tergantung di atas kayu salib pasti akan mati dan kemudian dikuburkan orang. J. B. Torrance mengatakan:

Salib dalam Perjanjian Baru menjadi lambang yang memalukan dan menghinakan, juga menjadi lambang hikmat dan kemuliaan Allah yang dinyatakan oleh salib itu sendiri. Orang Roma memakainya bukan hanya sebagai alat menyiksa dan menghukum mati, tapi juga sebagai alat untuk menghukum orang dengan cara yang memalukan di depan umum, yang disediakan bagi penjahat ulung dan keji. Bagi orang-orang Yahudi penyaliban berarti kutukan. (Ul. 21:23; Gal. 3:23).10

Ketika Yesus Kristus diputuskan untuk dijatuhkan hukuman salib oleh para pembesar dan orang banyak yang menginginkan Yesus Kristus harus disalibkan bukan karena kejahatan dan kesalahan Yesus Kristus, namun oleh karena rasa kebencian dan sakit hati kepada Yesus Kristus. Dan bagi orang banyak salib merupakan lambang dari penghinaan, kutukan dan memalukan, namun tidak bagi Allah. Justru bagi Allah sebenarnya salib yang dijadikan sebagai tempat untuk

${ }^{10}$ Torrance, Ensiklopedi Alkitab Masa Kini, 342. 
menyalibkan Yesus Kristus sebagai lambang hikmat dan kemuliaan Allah, karena dengan penyaliban Yesus Kristus di atas kayu salib dimana kemuliaan Allah justru dinyatakan kepada umat manusia yang berdosa. Salib Kristus merupakan wujud kasih Allah yang nyata bagi umat manusia, karena dengan penyaliban Yesus Kristus di atas kayu salib dimana semua orang bisa memperoleh hidup yang kekal dengan cara ketika seseorang percaya kepada Yesus Kristus sebagai Tuhan dan Juruselamat pribadi.

Salib juga melambangkan dua hukum kasih Allah yang diberikan kepada manusia yakni hukum vertikal (hubungan antara manusia yang berdosa dengan Allah yang Mahakudus) dan hukum horizontal (hubungan antara sesama manusia) yang terdapat dalam Injil Matius 22:37-40. Melalui salib manusia bisa membangun kembali persekutuan yang indah dengan Allah secara hubungan vertikal yang selama ini terputus dan hancur akibat dosa dalam diri manusia. Dosa membuat manusia menjadi seteru Allah dan manusia kehilangan hubungan vertikal yang indah dengan Allah, karena dosa membawa manusia semakin jauh dari Allah. Melalui salib juga dimana manusia bisa kembali membangun hubungan secara horizontal dengan sesama manusia. Sebab kasih yang telah manusia peroleh dari Allah ketika percaya kepada Yesus Kristus sebagai Tuhan dan Juruselamat pribadi, maka itulah yang bisa membawa manusia kembali membangun persekutuan secara horizontal antar sesama manusia.

Jadi salib bagi orang-orang dunia merupakan lambang yang kurang baik dan sangat menjijikan karena bagi orang banyak itu adalah tanda penghinaan dan kutukan yang seharusnya dihindari oleh manusia. Tetapi dari sudut pandang Allah justru berbeda dengan apa yang dilihat oleh kaca mata manusia yang telah dibutakan oleh dosa. Bagi Allah salib adalah lambang kemuliaan Allah dan sebagai tanda wujud kasih Allah nyata melalui penyaliban Yesus Kristus, karena dengan penyaliban Yesus Kristus di atas kayu saliblah manusia kembali menemukan dan mendapatkan identitas diri yang sesungguhnya, sehingga manusia dibebaskan dari hukuman kekal Allah, dan hidup bersama-sama dengan Allah.

Salib disediakan Allah bagi keselamatan manusia bukan secara kebetulan, namun semuanya itu Allah telah sediakan sejak masa kekekalan. Bagi Allah cara untuk menyelamatkan manusia dari dosa dan kebinasaan kekal Allah adalah melalui salib. Salib sebagai bukti kasih Allah yang nyata kepada manusia, sebab tanpa salib maka manusia tidak akan mungkin bisa diselamatkan dan manusia dipastikan akan menuju kepada kebinasaan. Bagi Allah dosa bisa diselesaikan hanya melalui kematian Yesus Kristus di atas kayu salib.

\section{Kematian Yesus Kristus Di Atas Kayu Salib}

Pada saat Yesus Kristus di atas kayu salib untuk menerima semua cawan murka Allah yang sempurna, menunjukkan satu keteladanan dan ketaatan Yesus Kristus sebagai Anak yang tidak pernah membantah dan juga tidak pernah melawan akan pekerjaan yang diberikan Bapa kepada-Nya. Ketaatan Yesus Kristus di atas kayu salib sampai kepada kematian tidak ada satu keluhan dan tidak ada penyesalan yang 
diperlihatkan oleh Yesus Kristus, karena Yesus telah mengetahui bahwa segala sesuatu yang telah diserahkan Bapa kepada-Nya harus dilakukan demi kepentingan seluruh umat manusia yang berbosa.

Yesus Kristus mati di atas kayu salib menunjukkan bahwa Yesus Kristus benar-benar manusia yang bisa mati, tetapi keAllahan Yesus Kristus tidak akan pernah mati sekalipun kemanusiaan Yesus Kristus telah disalibkan. Seringkali orang berpikir bahwa ketika Yesus Kristus disalibkan sebagai manusia yang tidak memiliki dosa dan mati di atas kayu salib, berarti bahwa jikalau Yesus Kristus sebagai Allah yang tidak bisa dipisahkan dengan kemanusiaan Yesus Kristus, maka itu berarti bahwa pada saat Yesus Kristus disalibkan sebagai manusia yang tidak berdosa tetapi dijadikan sebagai berdosa karena dosa umat manusia, maka keAllahan Yesus juga pasti ikut disalibkan dan mati, sehingga banyak orang beranggapan bahwa keAllahan Yesus Kristus pernah tersalib dan mati.

Hal ini yang perlu ditegaskan bahwa memang kemanusiaan dan keAllahan Yesus Kristus yang berbeda tetapi berada pada satu tubuh yang sama, namun tidak berarti bahwa ketika kemanusiaan Yesus Kristus disalibkan dan mati, maka keAllahan Yesus Kristus juga ikut disalibkan dan mati. Penegasan dalam hal ini bahwa yang disalibkan pada waktu Yesus Kristus berada di atas kayu salib hanyalah kemanusiaan Yesus Kristus saja, sedangkan keAllahan Yesus Kristus sama sekali tidak ikut disalibkan bahkan tidak mati sekalipun keAllahan Yesus Kristus pada saat kemanusiaan Yesus Kristus disalibkan dan mati. KeAllahan Yesus Kristus tidak pernah sedikitpun meninggalkan dan tidak terpisah dengan kemanusiaan Yesus Kristus dalam situasi dan kondisi terburuk sekalipun.

Yesus Kristus memiliki dan mempunyai dua sifat yang berbeda yakni sifat keAllahan dan sifat kemanusiaan yang melekat pada satu tubuh yang sama yakni di dalam Pribadi Yesus Kristus. Memang secara logika dan akalia manusia yang terbatas dan penuh dengan dosa sulit untuk bisa memahami dan mengerti keAllahan Yesus Kristus yang tidak ikut disalibkan dan tidak mati ketika kemanusiaan Yesus Kristus disalibkan dan mati. Manusia tidak mampu dan tidak dapat menyelami pikiran Allah, sehingga peristiwa penyaliban dan kematian Yesus Kristus di atas kayu salib dipandang sebagai suatu peristiwa yang tidak masuk akal, karena bagaimana mungkin keAllahan Yesus Kristus yang menyatu dengan kemanusiaan Yesus Kristus tidak dapat ikut disalibkan dan tidak mati ketika kemanusiaan Yesus Kristus disalibkan dan mati.

Semakin dalam manusia berusaha untuk mencari dan menemukan jawaban, namun sampai kapanpun manusia tidak bisa mendapatkan suatu jawaban yang dapat memuaskan logika dan akalia manusia, karena peristiwa kematian Yesus Kristus di atas kayu salib bukanlah pekerjaan dan rencana manusia, namun ini semua sudah ada dalam rencana kerja Allah sejak masa kekekalan.

Peristiwa kematian Yesus Kristus di atas kayu salib lebih melihat kepada kemanusiaan Yesus Kristus dibandingkan dengan keAllahan Yesus Kristus, sehingga pada waktu Yesus Kristus disalibkan dan mati, maka yang disalibkan adalah kemanusiaan-Nya saja dan bukan keAllahan-Nya. KeAllahan Yesus Kristus tetap ada 
dalam diri-Nya, tetapi tidak ikut disalibkan bahkan sampai mati, sehingga keAllahan Yesus Kristus sampai kapanpun tidak pernah mati dan tidak akan pernah mati di dalam diri Yesus Kritus, karena Yesus Kristus sebagai Allah telah ada sejak masa kekekalan yakni sebelum dunia dijadikan dan sekalipun dunia ini akan lenyap namun keAllahan Yesus Kristus adalah kekal dan abadi. Ada beberapa hal penting yang berkaitan dengan kematian Yesus Kristus di atas kayu salib yang dijabarkan sebagai berikut:

Pertama, Makna Kematian Yesus Kristus. Kematian Yesus Kristus di atas kayu salib bukanlah sebagai korban kejahatan yang telah dilakukan oleh Yesus Kristus, namun kematian Yesus Kristus di atas kayu salib memberi makna yang sangat mendalam bagi masa depan manusia. Kalau Yesus Kristus tidak mati di atas kayu salib maka hidup manusia pasti sia-sia dan hampa. Tidak ada gunannya manusia hidup di dunia ini lagi, karena sudah dapat dipastikan bahwa manusia setelah mati akan menuju kepada kebinasaan dan penghukuman kekal Allah akibat dosa yang ada dalam diri manusia.

Kematian Yesus Kristus memberikan pengharapan bagi masa depan manusia, sebab tidak ada seorangpun yang bisa sampai kepada Bapa di sorga kalau tidak melalui salib Yesus Kristus. Yesus Kristus mati di atas kayu salib mempunyai arti yang sangat besar bagi manusia. Ada satu pengharapan yang pasti dibalik kematian Yesus Kristus di atas kayu salib. Bagi orang-orang dunia salib merupakan lambang kutuk, memalukan, kekejian, hina dan penghukuman, tetapi bagi Allah makna salib Yesus Kristus di atas kayu salib sebagai lambang wujud kasih Allah yang nyata bagi manusia. Salib merupakan lambang dari kemuliaan Allah dinyatakan di dalam Diri Yesus Kristus.

Kematian Yesus Kristus di atas kayu salib tidaklah sia-sia bagi Allah dan manusia, namun justru memberi makna yang sangat mendalam mengenai kasih Allah yang benar-benar dinyatakan di dalam Diri Yesus Kristus kepada seluruh umat manusia yang telah berdosa kepada Allah. Arti dari kematian Yesus Kristus juga membawa kesukacitaan bagi seluruh umat manusia, karena kematian Yesus Kristus di atas kayu salib membuat setiap orang yang percaya kepada Yesus Kristus yang telah mati mendapatkan dan memperoleh hidup yang kekal.

Dalam Filipi 2:8 yang berbunyi: "Dan dalam keadaan sebagai manusia, Ia telah merendahkan diri-Nya dan taat sampai mati, bahkan sampai mati di kayu salib. Makna kata mati yang terdapat dalam Filipi 2:8 dalam bahasa Yunani dipakai kata $\theta \alpha \nu \dot{\alpha} \tau o u$ (thanatou) yang berasal dari kata $\theta \alpha \nu \alpha \dot{\tau} \tau \varsigma \varsigma$ (thanatos) yang mengandung arti "kematian, maut."11 Makna dari kematian Yesus Kristus di atas kayu salib menunjukkan bahwa secara kemanusiaan dimana Yesus Kristus benar-benar telah mengalami kematian dan seseorang yang telah mengalami kematian maka di dalam diri orang tersebut tidak ada kehidupan, sehingga pada waktu Yesus Kristus mati di

${ }^{11}$ Newman JR, Kamus Yunani - Indonesia Untuk Perjanjian Baru, hlm. 76. 
atas kayu salib menunjukkan bahwa di dalam kemanusiaan Yesus Kristus benarbenar tidak ada kehidupan yang ada pada Yesus Kristus.

Makna kematian yang lain juga bisa diartikan sebagai dosa, karena upah dosa ialah maut atau kematian kekal (Rm. 6:23). Hal ini ditegaskan oleh James H. Todd yang mengatakan: "Kematian berarti dosa, sebab "orang yang berbuat dosa, itu yang harus mati," dan "upah dosa ialah maut."12 Makna lain dari arti kematian Yesus Kristus di atas kayu salib adalah berkaitan dengan dosa, sebab dengan adanya dosa dalam kehidupan manusia yang membuat sehingga Yesus Kristus yang tidak berdosa telah dibuatnya menjadi berdosa karena dosa manusia, sehingga Yesus Kristus harus mati di atas kayu salib.

Dikatakan bahwa upah dosa adalah kematian kekal atau maut. Itu berarti bahwa ada hubungan yang begitu sangat erat antara kematian dengan dosa. Seandainya bila manusia tidak berdosa, maka Yesus Kristus juga pasti tidak akan mati di atas kayu salib, namun sejarah membuktikan bahwa manusia benar-benar telah jatuh ke dalam dosa yang membuat sehingga Yesus Kristus harus mati di atas kayu salib. Dosa membawa manusia tanpa terkecuali telah mengalami kematian kekal atau maut. Dosa harus diselesaikan dengan cara Yesus Kristus harus mati di atas kayu salib, karena hanya dengan salib dan kematian Yesus Kristus maka dosa manusia dapat diselesaikan dengan Allah.

Allah tidak menyediakan cara lain untuk dapat menyelesaikan dosa manusia selain melalui kematian Yesus Kristus di atas kayu salib, karena itu makna dari kematian Yesus Kristus membawa arti yang mendalam bagi masa depan manusia. Setiap orang yang tidak menerima salib kematian Yesus Kristus di atas kayu salib, maka makna salib kematian baginya tidak ada artinya sama sekali, karena itu agar manusia dapat merasakan makna dari kematian Yesus Kristus di atas kayu salib, maka manusia harus menerimanya lebih dahulu dengan tujuan agar benar-benar makna salib dari kematian Yesus Kristus di atas kayu salib membawa arti yang besar bagi masa depan manusia yakni dimana manusia tidak ikut dihukum dan tidak masuk dalam penghukuman kekal Allah.

Memang kematian Yesus Kristus di atas kayu salib memiliki banyak makna atau arti, namun semua makna memberikan arti penting bagi masa depan manusia, karena tidak ada satu makna dari kematian Yesus Kristus yang tidak memberikan pengharapan yang diperlukan oleh setiap manusia. Kematian Yesus Kristus di atas kayu salib bagi Allah merupakan cara Allah yang tepat yang telah disediakan Allah sejak masa kekekalan dengan tujuan untuk dapat menyelesaikan perkara manusia yang tidak bisa diselesaikan oleh manusia yakni berkaitan dengan dosa yang telah menjerat dan membawa manusia kepada penghukuman Allah. Manusia tidak bisa menyelesaikan dosanya dengan cara kerja manusia sendiri, itu sebabnya manusia membutuhkan Allah untuk dapat menyelesaikan dosa yang ada dalam diri manusia, sehingga Allah telah menentukan Yesus Kristus mati di atas kayu salib sebagai jalan penyelesaian.

12James H. Todd, Kristologi (Malang: Penerbit Gandum Mas, 2003), 7. 
Kedua, Pentingnya Kematian Yesus Kristus. Dosa merupakan persoalan besar sepanjang hidup manusia, sehingga kecenderungan manusia setiap saat ingin berbuat dosa, karena keseluruhan diri manusia telah tercemar dan terkontaminasi dengan dosa. Bagi manusia dosa merupakan hal yang harus segera diselesaikan dalam diri manusia dengan tujuan agar manusia tidak terpikat dan selalu hidup dikuasai oleh dosa.

Dosa tidak cukup diselesaikan dengan harta yang melimpah atau uang yang banyak, karena bagi Allah harta dan uang tidak diperlukan untuk menyelesaikan dosa yang telah menghancurkan seluruh kehidupan manusia. Persoalan dunia biasanya dapat diselesaikan dengan uang yang banyak atau harta yang melimpah, tetapi untuk menyelesaikan perkara dosa, maka diperlukan nilai pengorbanan yang sempurna yang kiranya dapat memuaskan hati Allah. Dosa di mata Allah sebagai perbuatan yang sangat menjijikan dan sangat dimurkai oleh Allah, karena bagi Allah dosa yang ada dalam diri manusia tidak cukup bila diselesaikan dengan memberikan uang yang banyak atau menyerahkan harta yang melimpah kepada Allah.

Allah pemilik alam semesta karena Allah yang telah menciptakan dunia dan segala isinya, sehingga uang yang banyak dan harta yang melimpah bagi Allah itu tidak berarti bagi Allah, sebab segala sesuatu yang ada pada Allah jauh melebihi uang yang banyak dan harta yang melimpah, sehingga manusia tidak bisa mencapai keselamatan dengan cara mengumpulkan uang dan harta yang banyak untuk membayar Allah dengan tujuan agar keselamatan dapat diberikan Allah kepada manusia.

Allah hanya mau menerima yang terbaik dari manusia yang harus setara dengan standar Allah sebagai Allah yang Mahakudus dan Mahasuci. Allah adalah Pribadi yang Mahakudus, sehingga setiap orang yang mau dan ingin datang kepada Allah harus juga memenuhi standar Allah yakni sebagai orang-orang kudus. Menjadikan manusia sebagai orang kudus tidak bisa diperoleh dengan perbuatan baik, uang dan harta yang melimpah, tetapi dengan cara menjadikan manusia sebagai ciptaan baru dan manusia baru yang memiliki kesetaraan dengan Allah sebagai orang kudus (2 Kor. 5:17), maka Allah dapat menerima kembali manusia untuk hidup bersama-sama dengan Allah selamanya.

Allah melihat bahwa untuk menjadikan manusia sebagai orang kudus tidak akan pernah ditemukan dalam diri manusia, karena semua manusia telah jatuh dalam dosa (Rm. 3:23), dan dosa dalam diri manusia membawa manusia kepada kematian yang kekal (Rm. 6:23). Oleh sebab itu Allah mengutus Anak-Nya Yesus Kristus datang ke dalam dunia untuk menjadikan manusia sebagai orang-orang kudus yang merupakan standar Allah agar manusia dapat diterima kembali oleh Allah (Yoh. 3:16; 14:6; Kis. 4:12). Yesus Kristus diutus oleh Allah dalam dunia ini selain melayani umat manusia dengan memberitakan Injil keselamatan kepada manusia, tetapi Yesus Kristus datang juga untuk mati di atas kayu salib (Mrk. 10:45). 
Yesus datang untuk menyerahkan nyawa-Nya artinya bahwa Yesus Kristus datang untuk mati di atas kayu salib.

Pentingnya kematian Yesus Kristus di atas kayu salib bagi manusia merupakan hal yang dinanti-nantikan dan diharapkan, karena dengan memahami dan mengerti arti dari kematian Yesus Kristus di atas kayu salib, maka manusia dapat menemukan jalan yang baik dan benar untuk datang kepada Allah. Hanya satu-satunya jalan yang harus dilalui oleh manusia untuk berjumpa dengan Allah dan menyelesaikan perseteruan dengan Allah dengan cara melalui kematian Yesus Kristus di atas kayu salib.

Setiap orang yang tidak memahami dan tidak mengerti mengenai makna dari kematian Yesus Kristus di atas kayu salib, maka manusia memandang salib kematian Yesus Kristus sebagai peristiwa yang tidak penting, sehingga sedikitpun tidak ada respon yang baik dari manusia. Manusia beranggapan bahwa masih ada cara lain yang bisa membawa manusia datang kepada Allah dengan cara melakukan perbuatan-perbuatan baik. Karena itu masih ada banyak orang yang masih memegang prinsip ini yakni melakukan perbuatan baik sebagai jalan yang bisa membawa manusia bertemu dengan Allah.

Perbuatan baik dan amal yang dipakai sebagai keyakinan oleh manusia sebagai jalan menuju kepada Allah, harus diingat bahwa ini bukan pikiran, rencana dan kehendak Allah tetapi ini semua karena pemikiran manusia sendiri. Manusialah yang menciptakan bahwa bila mana seseorang dapat mengamalkan segala perbuatan baik dalam dirinya, maka hal ini bisa membuat manusia pada akhirnya dapat bertemu dan berjumpa dengan Allah. Pemikiran seperti ini keliru dan salah, sebab menurut pandangan Allah bahwa untuk membuat manusia bisa datang dan berjumpa dengan Allah, maka manusia harus melalui salib kematian Yesus Kristus di atas kayu salib, karena dengan manusia percaya kepada Yesus Kristus yang telah mati dan bangkit dari antara orang mati, maka manusia dapat kembali bertemu dan berjumpa dengan Allah bahkan Allah saat itu juga menerima manusia menjadi anakanak Allah yang mewarisi kerajaan Allah (Yoh. 1:12).

Oleh sebab itu tidak ada alasan bagi manusia yang tidak melihat salib kematian Yesus Kristus di atas kayu salib sebagai hal yang penting bagi manusia. Setiap orang yang ketika telah memahami dan mengerti dengan baik pentingnya kematian Yesus Kristus di atas kayu salib, maka bagi setiap orang melihat hal ini sebagai keuntungan bagi masa depan manusia itu sendiri, karena dengan cara seperti inilah maka manusia pasti akan menemukan identitas dirinya yang sebenarnya dan jaminan keselamatan untuk memperoleh hidup yang kekal ketika manusia percaya hanya kepada Yesus Kristus saja. Itu sebabnya kematian Yesus Kristus di atas kayu salib benar-benar sangat penting bagi manusia itu sendiri yang tidak ingin mendapatkan hukuman kekal Allah di masa yang akan datang.

Ketiga, Tujuan Kematian Yesus Kristus. Allah dalam rencana masa kekekalan selalu merencanakan segala sesuatu tidak asal-asalan saja atau tidak sembarangan saja, namun dalam merencanakan segala sesuatu dimana Allah punya tujuan yang jelas dan berjalan sesuai dengan rencana kerja Allah tanpa ada intervensi dari 
manusia sedikitpun atau ciptaan Allah yang lain. Berkaitan dengan tujuan Allah bagi manusia yakni Allah ingin mengembalikan identitas manusia yang sesuai dengan harapan Allah yakni menjadikan manusia sebagai orang-orang kudus. Pada saat Allah menciptakan Adam dan Hawa sebagai manusia pertama, dimana Adam dan Hawa diciptakan sebagai manusia kudus dan suci, artinya bahwa dalam diri manusia tidak ada dosa di dalamnya. Namun ketika Adam dan Hawa telah melanggar perintah Allah dengan memakan buah pengetahuan yang dilarang Allah, maka sejak saat itulah manusia menjadi berdosa dan kehilangan kemuliaan dan kekudusan Allah.

Dengan hadirnya dosa dalam diri manusia, membuat manusia semakin jauh dan jahat di mata Allah. Allah melihat bahwa tidak ada cara dan jalan yang bisa ditempuh oleh manusia untuk menyelesaikan dosa dalam diri manusia, sehingga Yesus Kristus diutus oleh Allah datang ke dalam dunia yang berdosa agar manusia dapat kembali bersekutu dengan Allah dan menemukan kembali identitas manusia sebagai orang-orang kudus.

Salah satu tujuan dalam rencana kerja Allah dalam masa kekekalan adalah melalui kematian Yesus Kristus di atas kayu salib. Tujuan Yesus Kristus mati di atas kayu salib karena ada alasan yang kuat bagi Allah yakni untuk menebus dosa-dosa manusia. Untuk menebus manusia dari dosa-dosa yang telah diperbuat oleh manusia sebagai akibat dari suatu pelanggaran dan kesalahan manusia, maka kematian Yesus Kristus merupakan tujuan Allah yang sempurna. Karena bagi Allah tidak ada tujuan lain yang Allah dapat sediakan untuk dapat menebus segala dosadosa manusia, namun dengan cara melalui kematian Yesus Kristus di atas kayu salib, maka segala dosa manusia dapat diselesaikan oleh Allah di dalam Diri Yesus Kristus.

Tujuan kematian Yesus Kristus sangatlah jelas yakni hanya untuk menebus dosa-dosa umat manusia yang merupakan kekejian bagi Allah. Allah tidak punya motivasi dan tujuan lain melalui kematian Yesus Kristus. Kelahiran Yesus Kristus di kandang Betlehem sampai kepada kematian Yesus Kristus di atas kayu salib merupakan satu paket yang tidak bisa dipisahkan karena tujuan kelahiran Yesus Kristus yang kemudian akan menyelamatkan manusia dari dosa-dosa yang ada dalam diri manusia. Firman Tuhan dalam Matius 1:21 berbunyi: "Ia akan melahirkan anak laki-laki dan engkau akan menamakan Dia Yesus, karena Dialah yang akan menyelamatkan umat-Nya dari dosa mereka, sedangkan tujuan dari kematian Yesus Kristus di atas kayu salib untuk menebus pelanggaran-pelanggaran yakni dosa yang ada dalam kehidupan manusia yang tidak bisa diselesaikan oleh manusia. Firman Tuhan dalam Ibrani 9:15 berbunyi: "Karena itu Ia adalah Pengantara dari suatu perjanjian yang baru, supaya mereka yang telah terpanggil dapat menerima bagian kekal yang dijanjikan, sebab Ia telah mati untuk menebus pelanggaran-pelanggaran yang telah dilakukan selama perjanjian yang pertama."

Tujuan kematian Yesus Kristus di atas kayu salib jelas yakni hanya untuk menebus dosa-dosa dan pelanggaran-pelanggaran yang telah manusia lakukan di 
masa lampau, namun dampaknya masih terus terasa dalam kehidupan manusia masa sekarang. Dosa tidak akan pernah berhenti dan tidak berakhir dalam hidup manusia, dan dosa ini jugalah yang sedang menggiring dan membawa manusia menuju kepada penghukuman kekal Allah, tetapi hanya dengan kematian Yesus Kristus di atas kayu salib, maka manusia dapat terhindar dan terbebas dari hukuman kekal Allah. Hukuman kekal Allah diberikan kepada manusia yang berdosa tanpa adanya diskriminasi dan pilih kasih dalam kehidupan manusia.

Keempat, Hasil Dari Kematian Yesus Kristus. Tujuan yang ada dalam rencana kerja masa kekekalan Allah, pasti mempunyai hasil yang bisa dirasakan dan dialami dalam kehidupan manusia. Tidak mungkin Allah merencanakan segala sesuatu dengan tujuan yang rapih dan baik tersusun, tetapi tidak mempunyai hasil yang hendak dicapai dalam perencanaan kekekalan Allah. Segala sesuatu yang dimulai dengan suatu rencana tujuan yang baik dan jelas, maka pasti mengharapkan dan mempunyai suatu hasil yang hendak dicapai kemudian.

Manusia ketika merencanakan segala sesuatu untuk dikerjakan dan dilakukan pasti mempunyai suatu tujuan ke depan dan tujuan yang hendak dicapai tersebut karena manusia melihat hasil yang diperolehnya. Siapapun yang ingin merencanakan dan melaksanakan segala sesuatu pasti punya tujuan dan tujuan tersebut pasti ada hasilnya. Setiap orang yang tidak punya tujuan yang jelas dalam merencanakan segala sesuatu, maka hasil yang diharapkan juga tidaklah menjadi fokus, karena dalam merencanakan dan melaksanakan segala sesuatu tidak ada target yang hendak dicapai sebagai bentuk dari hasil yang ingin diperolehnya. Kalau manusia yang berdosa saja punya tujuan yang baik dan jelas sehingga mendapatkan hasil yang hendak dicapai di masa akan datang, lebih-lebih lagi dengan Allah sebagai pencipta alam semesta, ketika melakukan suatu tujuan maka ada hasil yang hendak Allah capai.

Setiap hasil yang hendak dicapai oleh Allah semuanya sangatlah jelas, karena dibangun dengan tujuan yang jelas dan benar. Hasil yang telah memuaskan hati Allah dengan kematian Yesus Kristus di atas kayu salib merupakan pekerjaan yang sempurna dan hal ini tidak bisa dilakukan dan dikerjakan oleh manusia yang penuh dengan dosa. Mengapa manusia tidak bisa melakukan dan tidak bisa melaksanakan segala sesuatu yang bisa memuaskan hati Allah, karena semua manusia tanpa terkecuali di mata Allah sebagai manusia yang berdosa dan tidak ada satu orangpun yang bisa memenuhi standar Allah, sehingga bagi Allah semua manusia tidak bisa dijadikan sebagai alat Allah untuk dapat mencapai hasil yang dapat memuaskan hati Allah. Satu-satunya manusia yang bisa memuaskan hati Allah adalah Yesus Kristus yang telah datang dari sorga di utus oleh Bapa dengan cara mati di atas kayu salib. Hasil yang dicapai oleh manusia melalui kematian Yesus Kristus di atas kayu salib sebagai berikut:

Pertama, manusia dibebaskan dari kuasa atau kutukan dosa, sehingga manusia tidak lagi dibawah kuasa dosa, melainkan manusia ketika percaya kepada Yesus Kristus, maka manusia telah menjadi anak-anak Allah dan dosa tidak berkuasa lagi dalam kehidupan manusia, karena yang berkuasa dalam diri manusia adalah Allah 
sendiri. Firman Tuhan dalam Roma 6:14 berbunyi: "Sebab kamu tidak akan dikuasai lagi oleh dosa, karena kamu tidak berada di bawah hukum Taurat, tetapi di bawah

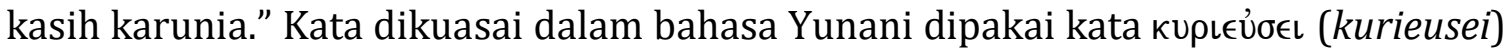

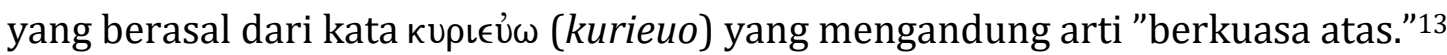

Manusia yang ada di dalam Yesus Kristus maka dosa tidak berkuasa atau dosa tidak mempunyai kuasa atas kehidupan manusia, sebab manusia sepenuhnya telah menjadi milik Allah. Manusia yang masih hidup dalam dosa, maka manusia akan tetap menjadi budak dan hamba dosa, tetapi setiap orang yang telah percaya kepada Yesus Kristus, maka manusia tidak lagi dikuasai oleh dosa, melainkan manusia telah berada di bawah kasih karunia Allah. Salah satu hasil dari kematian Yesus Kristus di atas kayu salib dimana manusia dilepaskan dari kuasa dosa dan kuasa kegelapan yang identik dengan dosa dan dipindahkan ke dalam Kerajaan Anak-Nya. Setiap orang yang ada di dalam Kristus, maka dosa tidak lagi berkuasa atas hidupnya, karena manusia telah dibeli dengan darah Yesus Kristus di atas kayu salib.

Kedua, manusia terbebas dari murka dan penghukuman kekal Allah. Murka dan penghukuman kekal Allah merupakan bagian yang akan diterima kelak oleh manusia yang benar-benar tidak mau bertobat dan tidak mau percaya kepada Yesus Kristus. Setiap orang yang tidak mau percaya kepada Yesus Kristus, maka salib baginya bukan hal yang penting untuk dimilikinya. Tetapi setiap orang yang sadar dan memandang salib kematian sebagai hal yang penting maka hasil yang diperoleh dimana manusia akan dibebaskan dari murka dan penghukuman kekal Allah.

Allah tidak pernah bermain-main dengan dosa, karena dosa bagi Allah adalah suatu kekejian yang sangat Allah murkai. Oleh sebab itu Allah sangat benci dengan dosa yang ada dalam kehidupan manusia yang membuat Allah murka kepada manusia bukan karena Allah benci kepada manusia, tetapi karena dosa yang melekat dalam kehidupan manusia, sehingga ketika Allah murka atas dosa manusia, maka kemanusiaanpun juga ikut merasakan murka dan penghukuman Allah. Tetapi bagi setiap orang yang telah dibenarkan oleh Allah ketika seseorang percaya kepada Yesus Kristus yang telah mati di atas kayu salib, maka Allah akan menyelamatkan setiap manusia yang telah percaya kepada Yesus Kristus dari murka Allah. Firman Tuhan berkata dalam Roma 5:9 berbunyi: "Lebih-lebih, karena kita sekarang telah dibenarkan oleh darah-Nya, kita pasti akan diselamatkan dari murka Allah." Kata

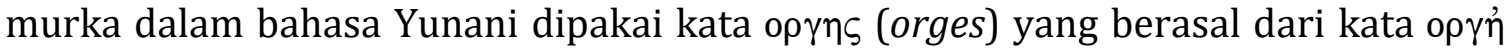
(orge) yang mengandung arti "murka, hukuman, kemarahan, amarah."14

Manusia yang percaya kepada Yesus Kristus akan diselamatkan dari hukuman atau kemarahan Allah atas dosa yang ada dalam diri manusia. Demikian juga bagi manusia yang percaya kepada Yesus Kristus bukan hanya diselamatkan dari murka Allah, tetapi Allah juga akan membebaskan manusia dari penghukuman, sehingga manusia yang telah percaya kepada Yesus Kristus melalui kematian-Nya di atas kayu salib baginya tidak ada lagi penghukuman baginya karena Yesus Kristus telah

${ }^{13}$ Newman JR, Kamus Yunani - Indonesia Untuk Perjanjian Baru, hlm. 97.

${ }^{14}$ Ibid. 118. 
menjadi jaminan bagi hidup kekal manusia seperti yang dikatakan oleh firman Tuhan dalam Roma 8:1 yang berbunyi: "Demikianlah sekarang tidak ada penghukuman bagi mereka yang ada di dalam Kristus Yesus." Allah menepati akan janji-Nya kepada manusia bahwa manusia yang telah percaya kepada Yesus Kristus sebagai Tuhan dan Juruselamat pribadinya maka tidak akan ada penghukuman atau hukuman, karena Yesus Kristus sebagai jaminan atas dosa manusia di hadapan Allah.

Ketiga, memperoleh hidup yang kekal. Hasil yang lain dari kematian Yesus Kristus yang bisa dirasakan oleh manusia sebagai pemuasan hati Allah adalah dimana manusia mendapatkan dan beroleh hidup yang kekal. Allah tidak ingin manusia binasa dan masuk dalam penghukuman kekal Allah akibat dari manusia selalu hidup dikuasai oleh dosa, tetapi Allah rindu agar kalau boleh jangan sampai ada satu orangpun yang akan binasa dan menerima penghukuman kekal Allah. Bagi Allah penghukuman adalah suatu tempat penderitaan selama-lamanya bagi manusia yang tidak mau bertobat dan tidak mau percaya kepada Yesus Kristus yang telah mati di atas kayu salib bagi keselamatan dosa umat manusia.

Allah telah menyediakan jalan keselamatan di dalam Yesus Kristus dengan tujuan supaya setiap orang yang percaya kepada Yesus Kristus tidak akan binasa melainkan beroleh hidup yang kekal (Yoh. 3:16). Kata beroleh dalam bahasa Yunani

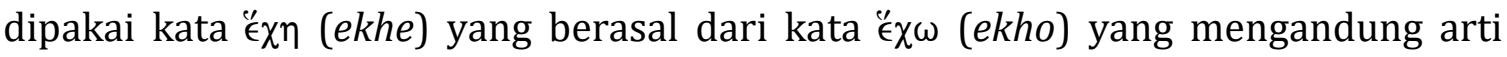
"mempunyai, memperoleh dan mendapatkan."15 Manusia yang percaya kepada Yesus Kristus maka hidup kekal benar-benar telah menjadi miliknya yakni dengan cara manusia telah mendapatkan, memperoleh atau memiliki hidup yang kekal itu. Artinya bahwa hidup kekal telah menjadi milik bagi manusia yang percaya kepada Yesus Kristus dan sampai kapan pun tidak mungkin akan diambil kembali oleh Allah atau Allah membatalkan karena dosa manusia, sebab Allah telah memberi kepada manusia yang percaya dan manusia yang percaya kepada Yesus Kritsus telah menjadikan hidup kekal sebagai miliknya.

Bahkan dengan tegas Yesus mengatakan bahwa tidak ada seorang di dunia ini sekalipun orang itu baik dan kaya yang bisa masuk dalam kerajaan Allah atau bisa berjumpa dengan Allah kalau tidak melalui Yesus Kristus (Yoh. 14:6). Yesus Kristus telah ditetapkan oleh Allah di dunia ini sebagai Juruselamat umat manusia, sebab di bawah kolong langit ini tidak ada satu orangpun yang bisa memenuhi standar Allah sebagai seorang Juruselamat karena semua orang telah jatuh dan telah berbuat dosa dan hanya Yesus Kristus satu-satunya yang telah memenuhi dan memuaskan hati Allah (Kis. 4:12).

Manusia yang ingin memperoleh hidup kekal maka hanya satu cara yang bisa didapatkan dan diperoleh oleh manusia yakni dengan percaya kepada Yesus Kristus yang telah mati di atas kayu salib sebagai Tuhan dan Juruselamat pribadinya, karena dengan cara inilah maka manusia pasti dijamin akan memperoleh hidup yang kekal dan pasti tidak akan mengalami murka dan penghukuman kekal Allah. Manusia

${ }^{15}$ Newman JR, Kamus Yunani - Indonesia Untuk Perjanjian Baru, hlm. 71. 
yang akan binasa bila manusia menolak untuk percaya kepada Yesus Kristus, karena semua kembali kepada kehendak bebas manusia untuk memilih tidak percaya kepada Yesus Kristus binasa, tetapi jika percaya kepada Yesus Kristus sebagai Tuhan dan Juruselamat maka pasti akan mendapatkan dan memperoleh hidup yang kekal.

\section{REFERENSI}

Alkitab. Jakarta: Lembaga Alkitab Indonesia, 2018.

Baker, David L. Satu Alkitab Dua Perjanjian. Jakarta: BPK Gunung Mulia, 2000.

Charley, J. W. Ensiklopedi Alkitab Masa Kini. Jilid 2. Diterjemahkan oleh M. H. Simanungkalit. Disunting oleh H. A. Oppusunggu. Jakarta: Yayasan Komunikasi Bina Kasih, 1997.

Daun, Paulus. Kristologia (Doktrin Tentang Allah), Pneumatologia (Doktrin Tentang Roh Kudus). Manado: Yayasan Daun Family, 2006.

Evans, Anthony T. Teologi Allah, Allah Kita Maha Agung. Malang: Yayasan Penerbit Gandum Mas, 1999.

Marantika, Chris. Masa Depan Dunia Ditinjau Dari Sudut Alkitab. Eskatologi. Yogyakarta: Iman Press, 2004.

Newman JR, Barcklay M. Kamus Yunani - Indonesia Untuk Perjanjian Baru. Diterjemahkan oleh John Miller \& Gerry van Klinken. Jakarta: BPK Gunung Mulia, 2012.

Packer, J. I. Knowing God. Diterjemahkan oleh Johny The. Yogyakarta: Penerbit ANDI, 2008.

Sappington, Thomas J. Hancurkan Kuasa Iblis Dalam Diri Anda. Yogyakarta: Penerbit Yayasan ANDI, 1998.

Siahaya, Johannis. "Misi Dalam Doa Yesus Menurut Yohanes 17." Jurnal Teruna Bhakti 1, no. 2 (2019): 19-20. http://ejournal.stakterunabhakti.ac.id/index.php/teruna/issue/archive.

Todd, James H. Kristologi. Malang: Penerbit Gandum Mas, 2003.

Tong, Stephen. Peta Dan Teladan Allah. Surabaya: Penerbit Momentum, 2013.

Torrance, J. B. Ensiklopedi Alkitab Masa Kini. Diterjemahkan oleh Harun Hadiwijono. Disunting oleh H. A. Oppusunggu. Jakarta: Yayasan Komunikasi Bina Kasih, 1997. 